\section{Etikk som verktøy}

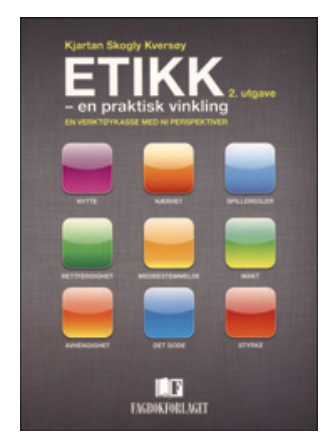

Kjartan Skogly Kversøy

\section{Etikk - en praktisk vinkling}

En verktøykasse med ni perspektiver. 2. utg. 153 s, ill. Bergen: Fagbokforlaget, 2012. Pris NOK 285

ISBN-978-82-450-1411-2

Målgruppen for denne lille og velskrevne teksten er alle som skal lære om etikk. Første utgave har vært brukt i grunnutdanningene til en rekke praktiske utdanninger, slik som for helsepersonell, førskolelærere, lærere, veiledere, politi og andre.

Andre utgave inneholder også en verktøykasse av spørsmål som skal hjelpe studenter ytterligere i det praktiske etikkarbeidet. De ni perspektivene som utgjør hoveddelen, er nytteetikk, nærhetsetikk, pliktetikk, rettferdighet, diskursetikk, maktperspektiv, avhengighet, dydsetikk og den sterkes perspektiv. Perspektivene presenteres på en kort og konkret måte med punktvis oppsummering og en vurdering av deres styrke og problemer.

Perspektivene vurderes i hovedsak ut fra tre kriterier: gjenkjennelighet, praktisk fungering og gavn. Forfatteren gir en praktiskøkonomisk begrunnelse for etikk, som er gjenkjennelig for mange av de yrkene den sikter seg inn mot. Dette er også svakheten, slik jeg ser det. Etikk reduseres til et verktøy i effektivitetens tjeneste. Selv om boken også omhandler det å bli et bedre menneske og det å ville andre vel, er det effektiviteten som er «bunnlinjen». Den anlegger derfor en «både/og- og verken/eller-strategi». Man kan velge i de ni perspektivene avhengig av hva man selv mener at situasjonen krever.

Med dette mister man to viktige aspekter ved etikk: kritisk refleksjon over (den praktiske) aktivitetens formål og etikken som refleksjon over det gode liv og samhandling som sådan. Etikk blir som regnskapsanalyse.

Den store styrken ligger i den pedagogiske fremstillingen av de ulike perspektivene. Forfatteren skal ha honnør for å gjøre vanskelige etiske teorier tydelige og forståelige. At mange nyanser og ulike varianter går tapt må man leve med i en innføringsbok. Â lese og lære mer kan man gjøre når interessen er fanget. I den forbindelse håper jeg at forfatteren også oppdaterer litteraturlisten ved neste utgave, som jeg er sikker på kommer om ikke så altfor lenge. Boken vil garantert bli lest av mange.

\section{Bjørn Hofmann \\ Høgskolen i Gjøvik \\ og}

Universitetet i Oslo

\section{Uferdige møter}

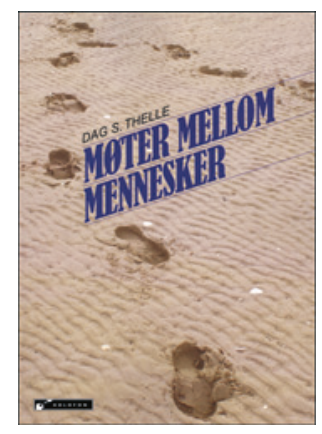

Dag S. Thelle
Møter mellom mennesker

87 s. Oslo: Kolofon forlag, 2013. Pris NOK 180 ISBN 978-82-300-1033-4

Dag Steinar Thelle er professor i epidemiologi og har jobbet mye med blant annet risikofaktorer for hjerte- og karsykdommer. I denne lille boken har han samlet 13 kortprosatekster som er i grenselandet mellom skjønnlitteratur og essayistikk. Tittelen antyder en rød tråd.

Som lege og forsker blir man rik på menneskelige erfaringer på godt og vondt. Teksten er et godt sted å reflektere over opplevelsene sine. Mange kunne ha godt av å gjøre det. I så måte er det flere fine anslag i Thelles bok, for eksempel i Foreleseren, om forskeren som strever med åpenheten fordi han er for opptatt av egen prestisje. Eller i En dag i oktober, hvor han beskriver en dag i en forskers liv nærmest som en bevissthetsstrøm. I andre tekster er det pasienter som har synsvinkelen.

Det er noe skisseaktig over denne boken. Skisser kan være interessante når de gir innblikk i en arbeidsprosess, for eksempel $i$ kunsthistorien. De kan vise oss at veien frem til et ferdig resultat kan være lang og strevsom. Her representerer de litt for ofte et råmateriale som burde vært mer gjennomarbeidet.

Thelle har lang erfaring med å skrive vitenskapelige artikler. Å skrive fiksjon er noe ganske annet enn å skrive faglitteratur. Det stiller andre krav til observasjon, iscenesettelse og historiefortelling. Klisjeen er den skjønnlitterære forfatterens største fiende, selv om den er aldri så sann. Det er ingen tvil om at Thelle kan skrive, men for meg blir det et problem at han ikke helt har funnet sin skjønnlitterære stemme. Kanskje ville forfatterens erfaringer og visdom kommet bedre til uttrykk i en rent faglitterær ramme? For eksempel i form av tematisk fokuserte essays?

\section{Anders Danielsen Lie \\ Oslo}

